\title{
A Systematic Review on Anti-tubercular Therapy induced Hepatotoxicity
}

\author{
Rashi bahuguna $^{a}$, Devesh Joshi ${ }^{a}$, Yogesh Joshi ${ }^{\mathrm{b}}$ \\ a Doctor of Pharmacy student Shri Guru Ram Rai Institute of Technology and Science, Patel Nagar, Dehradun, Uttarakhand, India. \\ ${ }^{b}$ Associate Professor Department of Pharmacy Practice, School of Pharmaceutical Sciences, Shri Guru Ram Rai University, Dehradun, \\ Uttarakhand, India. \\ *Corresponding author's E-mail: rashibahuguna@gmail.com
}

Received: 25-07-2021; Revised: 11-10-2021; Accepted: 20-10-2021; Published on: 15-11-2021.

\begin{abstract}
Tuberculosis is the leading cause of major morbidities and mortalities around the globe. One in every three persons suffers from tubercular infection in their lifetime. Antitubercular therapy-induced hepatitis occurs due to toxicity from the primary compound, metabolite, or an immunologically mediated response. Risk factors associated with hepatotoxicity are age, sex, low BMI, hypoalbuminemia, alcohol consumption, HIV, hepatitis B, and C. There are 6 major pathways by which anti-TB drugs are involved in hepatotoxicity including hampering of intracellular calcium homeostasis, derangement of actin fibril assembly that occurs next to the canaliculus, the drug binds to the heme-containing cytochrome $\mathrm{p}-450$ and forms enzyme-drug adduct and produces an immune response, The enzyme- drug addict when gets incorporated to vesicle acts as antigen for the production antibodies, some drugs also inhibit the $\beta$ oxidation and respiration and hence reduction in ATP production hence damaging cell and mitochondrial DNA, and some directly leads to apoptosis. Isoniazid is being metabolized to acetyl-isoniazid followed by hydrolysis to acetyl hydrazine via cytochrome P450 enzyme which produces toxic metabolites responsible for hepatotoxicity. Rifampicin activates the cytochrome enzyme and hence stimulates the production of harmful toxic materials leading to ATT-induced hepatotoxicity. It is the duty of the he pharmacist / medical staff has to provide the patient with adequate education about diseases and to inform them about their therapy regarding possible side effects and side effects. Pharmacists / medical staff must also train patients to comply with medication.
\end{abstract}

Keywords: ATT- Anti-Tubercular therapy, TB- Tuberculosis, ALT- Alanine amino transferase, AST- Aspartate amino transferase, ALPAlkaline phosphatase.

QUICK RESPONSE CODE $\rightarrow$

DOI:

10.47583/ijpsrr.2021.v71i01.007

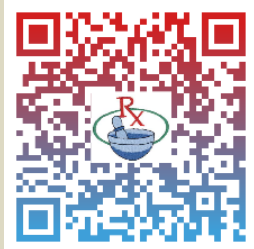

DOI link: http://dx.doi.org/10.47583/ijpsrr.2021.v71i01.007

\section{INTRODUCTION}

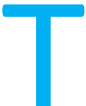

uberculosis is the leading cause of major morbidities and mortalities around the globe. One in every three persons suffers from tubercular infection in their lifetime. An estimated 9.6 million people suffered from TB and 1.5 million people died from the disease including 1.1 million HIV-negative persons and 400,000 HIV patients ${ }^{1}$.

Tuberculosis is an infectious bacterial droplet infection caused by Mycobacterium tuberculosis. The infected individual experiences cough with sputum and blood at times, chest pain, weakness, weight loss, night sweat, and fever ${ }^{2}$.

\section{Anti-tubercular therapy-induced hepatitis}

The First line anti-tubercular agents like Isoniazid $(H)$, Rifampicin (R), Pyrazinamide (Z), except Ethambutol (E) are hepatotoxic. The order of severity of hepatotoxicity caused by antitubercular therapy is Pyrazinamide $(9 \%)>$ Isoniazid $(3 \%)>$ Rifampicin $(1 \%)^{3}$. Hepatotoxicity is the most serious side effect of tuberculosis therapy ${ }^{4}$. Isoniazid shows elevations in transaminases levels in $10-20 \%$ of patients while precipitating hepatitis in $1 \%$ of patients ${ }^{5}$. Isoniazidinduced hepatitis is fatal in $8-10 \%$ of patients and is diagnosed with jaundice. Hepatotoxicity can occur due to Parent drug, drug metabolite or hypersensitivity reaction due to drug ${ }^{6,7}$.

Antitubercular therapy-induced hepatitis occurs due to toxicity from the primary compound, metabolite, or an immunologically mediated response. Risk factors associated with hepatotoxicity are age, sex, low BMI, hypoalbuminemia, alcohol consumption, HIV Hepatitis B and $\mathrm{C}^{8,9}$.

The time of onset of acute injury ranges from days to months after initiating a drug. Hepatotoxicity is presented with abnormalities of liver tests that include an increase in alanine aminotransferase (ALT), Alkaline Phosphatase (ALP), Bilirubin more than twice as normal ${ }^{10,11,12}$.

Stages of liver injury as per Chinese medical association ${ }^{13}$ The patient is categorized based on R-value

\section{$\mathrm{R}$-value is calculation}

Alanine Aminotransferase (ALT)/upper limit of normal (ULN) divided by alkaline Phosphatase

$$
R=\left\{\frac{A L T}{U L N}\right\} / A L P
$$


Hepatocellular injury, ALT xULN divided by ALT/ALP >=5;

$$
\text { Hepatocellular injury }=\frac{\{A L T * U L N\}}{\left\{\frac{A L T}{A L P}\right\}}=\geq 5
$$

Cholestatic injury, ALP $\times U L N$ divided by ALT/ALP $<2$;

$$
\text { Cholestatic injury }=\frac{\{A L P * U L N\}}{\left\{\frac{A L T}{A L P}\right\}}<2
$$

Hepatocellular-cholestatic mixed injury, ALT×ULN, ALP×ULN divided by ALT/ALP is between 2 to 5 .

Classification based on severity of drug-induced hepatic injury as per American grading scale.

Based on severity, Drug-induced Liver Injury is classified into five Grades ${ }^{14-17}$

\section{Grade 1 (mild liver injury)}

The serum level of alanine transferase or alkaline phosphatase in patient is elevated, but total bilirubin (TBIL) $<2.5$ ULN $(2.5 \mathrm{mg} / \mathrm{dl}$ or $42.75 \mathrm{~mol} / \mathrm{L})$ without coagulation dysfunction (International normalized ratio ( $R$ factor) $<1.5)$;

\section{Grade 2 (moderate liver injury)}

Increased serum levels of alanine transferase or alkaline phosphatase, and TBIL >= 2.5 ULN or coagulation dysfunction ( $R$ factor $>=1.5)$ despite lack of hyperbilirubinemia.

\section{Grade 3 (severe liver injury)}

Elevation in serum amino transferase and/or alkaline phosphatase, TBIL >=5ULN ( $5 \mathrm{mg} / \mathrm{dl}$ or $85.5 \mathrm{~mol} / \mathrm{L}$ ), with or without $\mathrm{R}$ factor $>=1.5$ and require hospitalization for druginduced liver injury (or prolonged hospitalization);

\section{Grade 4 (acute liver failure)}

Abnormality in the coagulation is denoted by $\mathrm{R}$ factor $>=1.5$ or PTA (prothrombin activity) $<40 \%$, hepatic encephalopathy, and TBIL >=10 ULN (10 mg/dl or 171 Imol/L) or daily increase by $1.0 \mathrm{mg} / \mathrm{dl}(17.1 \mathrm{~mol} / \mathrm{L})$ in 26 weeks after the onset of Drug-Induced Liver Injury. There may be an accumulation of fluid in the peritoneal cavity which may lead to pain, inflammation or both. DrugInduced Liver Injury also leads to organ dysfunction.

\section{Grade 5 (fatal)}

It is the condition of liver dysfunctioning or liver failure hence there is a need for a liver transplant for survival Grade I grade II and grade III liver injuries are successfully treated with any operative measures or Non-Operative Management (NOM) but Grade IV and Grade V require operative management.

\section{Epidemiology}

The incidence of drug-induced hepatitis during multidrug resistance therapy for tuberculosis is $2 \%$ to $28 \%{ }^{18,19}$. An analysis of pooled data from four prospective Indian studies 20, 21 shows that the calculated hepatitis risk is between 11 and 5\%. A meta-analysis of 14 studies published in the West found a risk of $4 \%$ to $28 \%$. The reasons for this higher incidence of hepatotoxic reactions in India are unclear ${ }^{22} 23$.

\section{MATERIALS AND METHODS}

\section{Pathophysiology of Drug Induced Hepatotoxicity}

Intracellular calcium homeostasis hampering deranges the actin-fibril assembly at the hepatocyte surface and this forms blebs on the cell membrane ultimately rupturing them ${ }^{24,25}$. Fig: $1 \mathrm{~A}$

Actin-fibril assembly arrangement is disturbed and may occur next to canaliculus in patients with the cholestatic disease. This disruption of assembly can cause interruption of the MRP-3 transport pump which in turn prevents bilirubin and other organic compounds excretion. Toxic substances like bilirubin and bile are accumulated in liver cells rendering the liver injury ${ }^{26}$. Fig: $1 \mathrm{~B}$

The enzyme cytochrome $\mathrm{P}-450$ in the endoplasmic reticulum contains heme that binds to the drug-producing drug-enzyme adduct. This adduct creates an immune response when it binds to the cell membrane and damages the liver ${ }^{27}$. Fig: $1 \mathrm{C}$

The enzyme-drug adduct enters the vesicle and creates an immune response to activate cytolytic $\mathrm{T}$ cells and cytokines, ultimately destroying the entire liver cell ${ }^{27}$. Fig:1 D

The drugs also inhibit $\beta$-oxidation and respiration, which leads to decreased ATP production. This leads to anaerobic respiration in liver cells and decreases the metabolism of fatty acids, lactate and reactive oxygen species. Ultimately, lactate builds up in cells and reactive oxygen species, destroying DNA and cells ${ }^{28}$. Fig:1 $\mathrm{E}$

The drug acts as a reactive metabolite and this leads to the binding of TNF- $\alpha$, and Fas at TNF- $\alpha$ and the Fas receptor and thus activates caspase enzymes and ultimately leads to apoptosis of liver cells ${ }^{29}$. Fig: $1 \mathrm{~F}$

\section{Isoniazid induced hepatotoxicity}

Isoniazid is the principal accused drug in anti-tuberculosis drug prompted hepatotoxicity. It is observed that $10 \%$ $20 \%$ of sufferers develop moderate hepatic disorder throughout the preliminary 4-6 months of therapy with a boom in ALT, AST and bilirubin concentrations. If the drug is continued after the onset of the symptoms, the frequency that is responsible for $6-12 \%$ mortality is $15 \%$ $36 \%{ }^{30}$.

Isoniazid is metabolized to acetyl isoniazid in the presence of N-acetyltransferase (NAT) when subjected to Phase 1 toxification. This step is followed by hydrolysis to mono acetyl hydrazine (MAH) ${ }^{31}$.

Monoacetylhydrazine is oxidized in the presence of the microsomal enzyme cytochrome P4502E1 to acetyl 
hydrazine, which is ultimately oxidized to hepatotoxins, which leads to cell necrosis or apoptosis ${ }^{32,33}$.

In the presence of $\mathrm{N}$-acetyltransferase-2 (NAT-2), acetyl hydrazine is acetylated to diacetyl hydrazine, which is nontoxic, and this is phase 2 of liver poisoning ${ }^{34}$.

Isoniazid can also be hydrolyzed directly to hydrazine, a highly toxic metabolite that causes cell damage ${ }^{35}$, without acetylation. Fig:2

According to the NAT-2 genotype studies, slow acetylators have a higher risk of hepatitis caused by anti-tuberculous therapy ${ }^{30,35,36,37}$.

\section{Rifampicin induced hepatotoxicity}

Rifampicin increases levels of liver enzymes in the liver within 8 weeks of treatment. The combination of isoniazid and Rifampicin shortens the duration of the development of hepatotoxicity, as rifampicin accelerates the formation of toxic metabolites by activating the production of cytochrome P-450, which leads to cell damage ${ }^{38}$.

Rifampicin metabolizes to deacetyl rifampicin and 3 formyl rifampicin through the deacetylation process. Deacetyl rifampicin is a non-toxic metabolite and produces antibacterial activity ${ }^{39}$. Fig: 2

\section{Pyrazinamide induced hepatotoxicity}

Pyrazinamide is the prodrug of pyrazinoic acid, an active metabolite of the drug. Pyrazinamide is converted to pyrazinoic acid or 5-hydroxypyrazinamide. Both metabolites are then converted to 5-hydroxypyrazinoic acid, which is naturally highly toxic ${ }^{40,41}$. Fig: 3

\section{Ethambutol induced hepatotoxicity}

Ethambutol induced liver toxicity is very rare but it can cause abnormal liver functions ${ }^{40,41}$.

\section{Fluoroquinolones induced hepatotoxicity}

Fluoroquinolone-induced liver injury occurs primarily due to hypersensitivity reactions associated with peripheral eosinophilia and fever.

\section{Type 1 anaphylactic hypersensitivity reaction}

When the antigen comes into contact with the host organism, it binds to B cells that contain IgE antibodies. This process is known as sensitization.

After sensitization, plasma cells are activated, which then release IgE antibodies.

Secreted IgE antibodies bind tightly to Fc receptors on basophil mast cells, which damage the cell membrane and lead to the ingress of sodium and water, which leads to mast cell degranulation. The released granules contain enzymes and inflammatory mediators such as vasoactive peptide (VIP), leukotrienes, neutrophils, eosinophils, platelets activating factors etc ${ }^{42}$. Fig: 4

Type- 4 delayed hypersensitivity reaction
Antigen comes in contact with CD8+ T-cell after entering the host cell and is processed by an antigen-presenting cell.

Antigen-presenting cell migrates to the lymph nodes and presents the antigen to the helper CD4+ T-cell.

CD4+ T-cell releases the cytokines that stimulate the proliferation of $t$-cells and activates the macrophages.

Activated T-cell and macrophages release the inflammatory mediators that cause cell destruction and allergic menifestations ${ }^{42}$. Fig: 5 .

\section{Streptomycin}

Streptomycin is not responsible for any type of hepatotoxicity ${ }^{40,41}$.

\section{Risk Factors}

Growing countries have a peak incidence of TB therapyinduced hepatotoxicity because it varies around the world and elements such as chronic liver disease, careless drug use, malnutrition, and advanced tuberculosis are common in growing countries $43,44,45$. Hepatitis is characterized as $8 \%-19 \% 46,47,48$ in Asia, $3 \%{ }^{49}$ on the west side and $8 \%{ }^{50}$ in Nepal. The patient-to-patient variant for ATT-induced hepatotoxicity, in general, occurs due to the individual characteristics of the data subject, such as specific treatment regimens using specific monitoring systems and specific diagnostic standards defining hepatoxicity ${ }^{51}$.

\section{Age}

The incidence of ATT-induced hepatitis becomes more likely with age, $52,53,54,55$. The rate of ATT-induced hepatitis with increasing age is given as $2 \%$ to $8 \%$, with an average of $5 \%{ }^{56}$. With $25.8 \%$ and $14.4 \%$ respectively, people are more affected than the younger population; older people with other comorbidities may be more affected ${ }^{57}$.

\section{Sex}

Women are at an increased risk of developing ATT-induced hepatotoxicity due to variations in pharmacokinetics and slower acetylation pattern and a lower body mass index of ${ }^{58}$. Women are reported to be at an increased risk compared to men when it comes to the development of ATT-induced hepatotoxicity ${ }^{59,60}$. One study reported a higher incidence in women than men $(26.3 \%$ versus $19.7 \%)^{61,62}$. CYP3A activity is higher in women, making them more prone to hepatotoxicity ${ }^{62}$.

\section{Alcohol}

Alcohol is responsible for stimulating the liver enzyme cytochrome P-450; hence creating toxic metabolites that is responsible for liver damage. Alcohol in the presence of alcohol dehydrogenase and cytochrome P-450 is converted to acetaldehyde. Acetaldehyde produces acetate in the presence of acetaldehyde dehydrogenase. Acetate in the presence of acetyl-CoA synthase is converted to acetyl-CoA, which is the main toxic metabolite that causes hepatotoxicity. Alcohol, along with isoniazid, increases the severity of hepatotoxicity, since 
both produce toxic substances in the presence of cytochrome P-450 ${ }^{61,62}$. Fig: 6

\section{Malnutrition}

Malnutrition in tuberculosis patients is the major cause of ATT-induced hepatitis as it leads to depletion of glutathione stores, making patients more susceptible to oxidative injury and low drug metabolism ${ }^{63,64}$. Adequate nutrient intake is important for liver metabolism and drug detoxification of Anti TB drugs, as the enzyme system of cytochrome P450 is influenced by nutrient uptake, fasting, and malnutrition ${ }^{65,66}$.

\section{Type of tuberculosis}

It has been reported that patients with extrapulmonary tuberculosis are at increased risk of developing druginduced hepatotoxicity and most of them have abdominal tuberculosis ${ }^{67}$.

\section{Concomitant infection}

The first event in the pathophysiological process of hepatotoxicity is due to the inflammatory response due to a concomitant infection ${ }^{68}$.

\section{Hepatitis C carrier}

It has been reported that approximately $30 \%$ of people infected with hepatitis $\mathrm{C}$ developed hepatotoxicity induced by anti-tuberculosis therapy, while $11 \%$ were infected without hepatitis $\mathrm{C}$ and therefore hepatitis $\mathrm{C}$ was an independent risk factor for hepatotoxicity ${ }^{69}$.

\section{Human Immunodeficiency Virus}

HIV infection and viral hepatitis increase the risk of ATTinduced hepatotoxicity by 3 to 5 times $^{70}$.

\section{Hepatitis B virus}

ATT-induced hepatotoxicity risk is higher in patients with chronic hepatitis B virus compared to uninfected people. It is also reported that the severity of hepatotoxicity is directly related to the viral load at the time of initiation of anti-tuberculosis therapy ${ }^{71}$.

\section{Treatment}

Anti-tuberculous drug therapy should be stopped immediately and non-hepatotoxic drugs with ethambutol, streptomycin, and fluoroquinolones should be started ${ }^{\mathbf{7 2}}$.

Wait for the LFT to verify that the enzymes have returned to normal and the clinical side effects have subsided before reintroducing the TB drugs. Reduce jaundice before antiTB drugs start. If hepatotoxicity does not settle begin a non-hepatotoxic regimen of Ethambutol streptomycin and Fluoroquinolones for 18-24 months ${ }^{72}$.

Once ATT-induced hepatitis subsides, reintroduce the drugs one at a time. If symptoms return after some time or liver function tests become abnormal again, the most recently started medication should be discontinued. It is recommended to start with rifampin as it is less toxic than isoniazid and pyrazinamide will restart and isoniazid will restart after 3 to 7 days ${ }^{72}$.

Possible drug regimens are ${ }^{73}$.

\section{Hepatotoxic two-drug regimen}

Patients are either prescribed Isoniazid and rifampin plus ethambutol for 9 months or Isoniazid, rifampin, streptomycin, and ethambutol for 2 months, followed by isoniazid and rifampin for 6 months or Rifampicin, pyrazinamide, for 6 months -9 months

A hepatotoxic drug: Isoniazid, ethambutol, and streptomycin for 2 months, followed by isoniazid and ethambutol for 10 months.

\section{Without hepatotoxic drug}

Hospital patients with advanced or portosystemic cirrhosis

\section{Use of Hepatoprotective Agent}

\section{UDCA}

UDCA, a hydrophilic dihydroxylated bile acid, was first recognized as the main component of the dried bile of the Chinese black bear ${ }^{74,75}$. The mechanism of action of UDCA is as follows:

(1) Replacement/displacement of toxic endogenous bile acids,

(2) Cytoprotective effects on hepatocytes and bile duct epithelial cells,

(3) Immunomodulatory effects

(4) Stimulation of bile secretion by hepatocytes and bile duct epithelial cells ${ }^{76,77}$.

\section{SNMC}

SNMC is a drug that is administered intravenously and contains glycyrrhizin as its main component, as well as glycine and L-cysteine with an unknown mechanism of action ${ }^{78}$.

\section{Glycyrrhizin}

Glycyrrhizin is made up of one molecule of glycyrrhetinic acid and two molecules of glucuronic acid and hence is a conjugated molecule that is extracted from Glycyrrhiza glabra plant roots. The mechanism of action of glycyrrhizin is not known yet. Heptagon, udiliv, and pyridoxine are also hepatoprotective agents ${ }^{78}$.

\section{Prevalence of ATT-Induced Hepatotoxicity in Tuberculosis Patients Based on Few Studies.}

In a study by Sana Sehar, Afia Munir, Tooba Chandni, and Muhammad Ahmad Department of Pulmonology, Sheikh Zayed Hospital, Rahim Yar Khan out of 150 Tuberculosis Patients 17 developed Anti- Tubercular therapy-induced Hepatitis, among them 10 were males and 7 were females i.e., Higher incidence of ATT Induced hepatitis was seen in males. It was found that the Incidence of Antitubercular therapy-induced Hepatitis was highest i.e., 22.5\% among 
the Patients who belong to the age group of 49 to 60 years $^{79}$.

In a research work by Jagdeep Singh, Pramod K. Garg, V. S. Thakur, and Rakesh K. Tandon Department of Gastroenterology of All India Institute of Medical Sciences two groups were studied i.e., Control group of 45 Tuberculosis Patients and a Study group of 40 Tuberculosis Patients with Anti-tubercular Therapy induced Hepatitis, Among Patients of Study group 23 were males and 17 were females i.e., Higher incidence of ATT Induced hepatitis was seen in males. A higher rate of Incidence was seen in patients of mean age $37.82 \pm 10.01$. 2 Patients were chronic alcoholic, 3 Patients were having Chronic Liver Disease and there was no HBV carrier ${ }^{80}$.

In a study by J N Pande, S P N Singh, G C Khilnani, S Khilnani, $\mathrm{R} K$ Tandon two groups were studied i.e., Control group of 406 tuberculosis patients and a study group of 86 Tuberculosis Patients with Anti-tubercular therapy induced Hepatitis, the male and female ratio of patients with ATT Induced Hepatitis was 1.26. Higher rates of Incidence were seen in patients of mean age $39.0 \pm 16.2$. The average weight of the ATT Induced Hepatitis patients is $48.6 \mathrm{~kg}$, Height is 1.7 meters and BMI is $18.1 \mathrm{~kg} / \mathrm{m}^{37}$

In a study by Nabi Rahman*, Sajjad Ali*, Muhammad Yousaf Khan*, Muhammad Umar*, Zafar Iqbal*, Anila Basit*, Zia Ullah*, Arshad Javaid* 73 Anti-tubercular therapy-induced Hepatitis Patients were admitted in the hospital $39(53.40 \%)$ out of them were females and 34 (46.60\%) were males females i.e., Higher incidence of ATT Induced hepatitis was seen in females. Patients of the age group of $>35$ years had a higher incidence of developments of ATT-induced hepatitis with $71.23 \%{ }^{81}$.

In a Research work by K.C. Chang*, C.C. Leung*, W.W. Yew, and C.M. Tam* cohort study was performed on 3007 tuberculosis patients receiving Anti-Tubercular therapy, 167 out of them developed ATT induced Hepatitis, and 96 Patients were taken as the cases. The study explained that sex had no impact but age is associated with increased risk of development of Hepatitis from $2.6 \%$ to $4.1 \%$ above the age of 49 years $^{82}$.

A case-control study performed by J Singh, A Arora, PK Garg, VS Thakur, JN Pande, RK Tandon was performed in 60 Tuberculosis Patients with ATT induced Hepatitis, The sex ratio was found to be 33:27 and the mean age of the Patients was $40.76 \pm 18.02$ and the majority of the cases were between the age group 14-50 years with 69 years. $6.67 \%$ of patients were found to be chronic Alcoholic ${ }^{83}$.

In Research performed by M Irfan Malik, Hafiza Shafia Naz, Ghias UI Hassan, the study was performed on 95 Pulmonary Tuberculosis Patients, and 35 out of them developed ATT induced Hepatitis, Mean Age of the patients with ATT induced Hepatitis was found to be $37.9 \pm 14.5$ in the age group $16-65$ years. Jaundice was seen in 38 (40\%) Patients. Deranged AST and ALT were seen in $34(35.8 \%)$ patients and increased bilirubin was seen in $35(36.8 \%)$ patients ${ }^{84}$.
A study was performed by Munir Ahmad Abbasi, Naseer Ahmed, Amir Suleman, Haidar Zaman, Sumbal Tariq, Syed Abbas Anwar, Nisar Khan on 179 Tuberculosis patients 22 out of them developed ATT induced Hepatitis, out of 22 (12.29\%) patients 10 were females and 13 were males, The mean age of patients with ATT induced Hepatitis was 36.51 \pm 9.5 years i.e., $20-59$ years ${ }^{85}$.

A Research study was performed by Sumbal Tariq, Tahir Saleem Khan, Saqib Malik*, M. Shamim Anwar*, Abdul Rashid on 500 Tuberculosis Patients, and 40 out of them developed ATT induced Hepatitis i.e., 8\%, including 20 Males i.e., $7.2 \%$ and 20 females i.e., $8.96 \%$. Transaminases were raised in 19 patients i.e., $3.8 \%$ and 21 i.e., $4.2 \%$ patients developed overt hepatitis out of them 7 were males and 14 were females, and one i.e., $0.2 \%$. The male died of Acute Fulminant Hepatitis, while 20 improved after excluding INH and giving split ATT ${ }^{86}$.

In a Study done by Bijay Bartaula*, Bickram Pradhan, Narendra Bhatta, Naveen Kumar Pandey, Dharani Dhar Baral, Bandana Mudbhari, on 162 Tuberculosis Patients, 34 i.e., $22.98 \%$ out of them developed ATT induced Hepatitis with 23 males and 11 females, among these 34 patients 6 developed nausea, 13 developed jaundice, 7 suffered from vomiting and 8 developed anorexia. 18 Patients out of them were Alcoholic and 16 were Non -Alcoholic while 12 were smokers and 22 were Non-smoker ${ }^{87}$.

In a Research by Gajanan S. Gaude, Alisha Chaudhury, Jyothi Hattiholi 150 Drug- Induced liver injury Patients were studied out of them 95 were males and 55 were females and maximum patients were of the age group 4060 years i.e., 54 patients with 59 patients having a history of Alcohol consumption ${ }^{88}$.

In a study performed by Khalid Mahmood Hussain, Akhtar Hussain, Krishan Lal Jairamani, Abu Talib, Badar-Uddin Abbasi, S. Salkeen, 67 Patients out of 339 Tuberculosis Patients developed ATT induced Hepatitis, 38 Patients i.e., $11.2 \%$ had minor derangement i.e., 3 to 5 times of normal 14 Patients were having severe alterations, while 15 patients showed moderate derangement ${ }^{89}$.

In a research study done by Haji Khan Khoharo, Shuaib Ansari, Ali Akber Siddiqui, Fatima Quresh 91 i.e., 26\% Patients out of 350 Tuberculosis Patients developed ATT induced Hepatitis with alanine transaminase (ALT) rise noted i.e., 48 (52.75\%), 40 (43.95\%) and 3 (3.3\%) as minor, moderate and severe case respectively. Individual drug toxicity was noted as Isoniazid with 53 i.e., 58.24\% Patients, rifampicin with 32 i.e., $35.16 \%$ Patients, and pyrazinamide (PZA) with 6 i.e., 6.59\% Patients respectively 90. 


\section{RESULTS AND DISCUSSIONS}

Table 1: Liver injury Scale according to American association for the surgery of trauma (AAST) ${ }^{17}$

\begin{tabular}{|c|c|c|}
\hline Grade & Injury Type & $\begin{array}{l}\text { Description of Injury } \\
\text { (imaging, operative } \\
\text { and pathologic criteria) }\end{array}$ \\
\hline \multirow{2}{*}{ Grade I } & Hematoma & $\begin{array}{l}\text { Subcapsular } \\
\text { Hematoma }<10 \% \\
\text { surface area }\end{array}$ \\
\hline & Laceration & $\begin{array}{l}\text { Parenchymal } \\
\text { Laceration }<1 \mathrm{~cm} \\
\text { deapth }\end{array}$ \\
\hline \multirow[t]{2}{*}{ Grade II } & Hematoma & $\begin{array}{l}\text { Subcapsular hematoma } \\
10-50 \% \text { surface area, } \\
\text { Intraparenchymal } \\
\text { hematoma }<10 \mathrm{~cm} \text { in } \\
\text { diameter }\end{array}$ \\
\hline & Laceration & $\begin{array}{c}\text { Parenchymal } \\
\text { Laceration } 1-3 \mathrm{~cm} \text { in } \\
\text { deapth and }=<10 \mathrm{~cm} \\
\text { length }\end{array}$ \\
\hline Grade III & Hematoma & $\begin{array}{c}\text { Subcapsular } \\
\text { Hematoma }>50 \% \\
\text { surface area required, }\end{array}$ \\
\hline
\end{tabular}

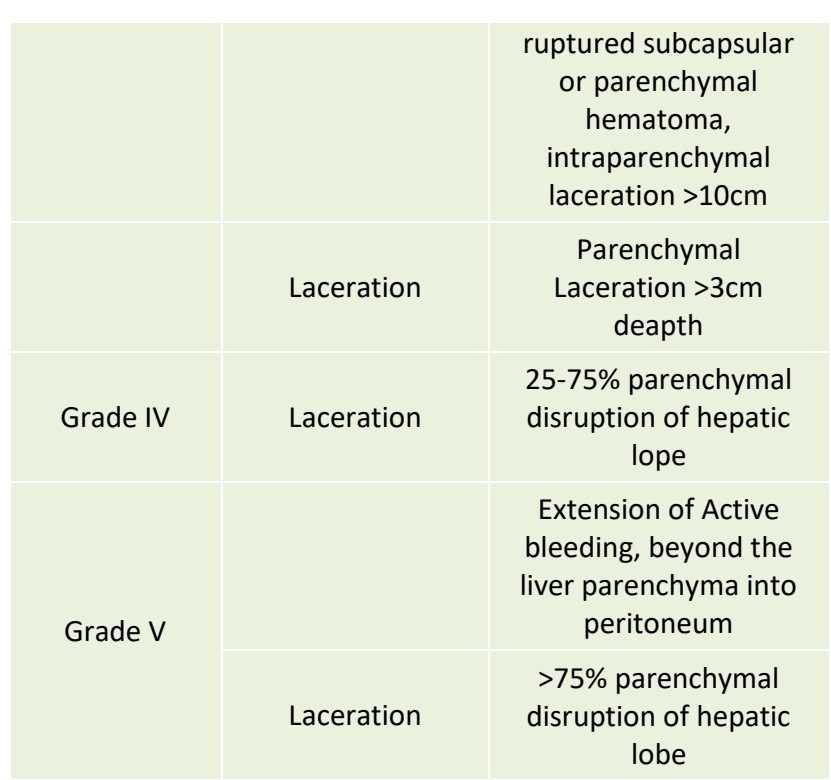

Five Grades of liver injury with injury type and their imaging, operative, and pathologic criteria are summarised in table.

\section{Figures}

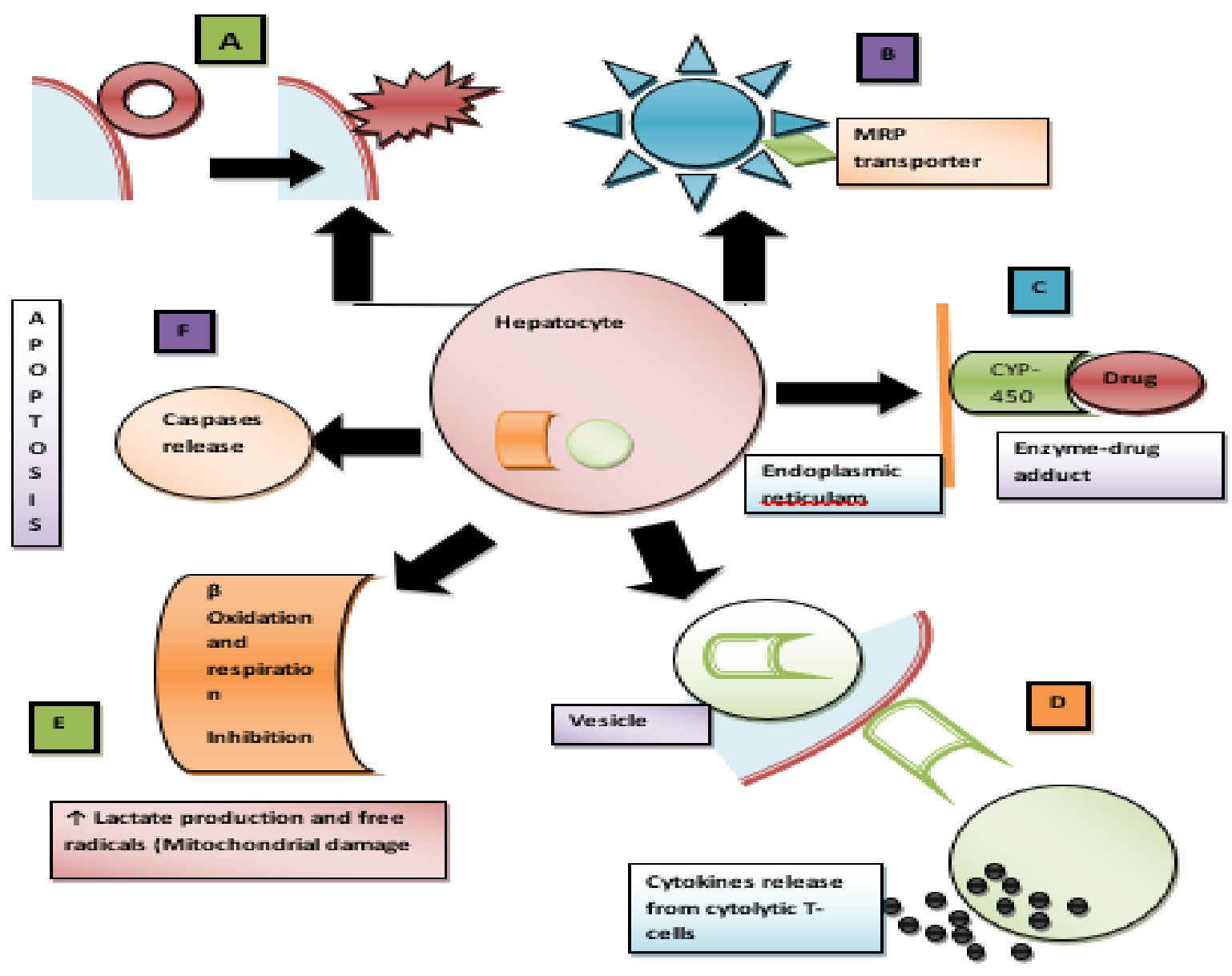

Figure 1: Pathophysiology of drug induced hepatotoxicity ${ }^{24-29}$ 


\section{Figure1}

Intracellular calcium homeostasis hampering form blebs on the cell membrane and rupture the hepatic cell membrane, (B) Actin-fibril derangement next to canaliculus in hepatocyte cause interruption of the MRP-3 transport pump which in turn prevents bilirubin and other organic compounds excretion. (C) Drug- enzyme adduct formation takes by binding to heme in CYP-450. This adduct produces an immune response to damage liver cells. (D) Enzyme-drug adduct enters the vesicle and creates an immune response to activate cytolytic $T$ cells and cytokines, ultimately destroying the entire liver cell (E) Drug inhibit $\beta$-oxidation and respiration leading to anaerobic respiration in liver cells. This produces reactive species responsible for damaging liver cells. (F) The drug binds to TNF- $\alpha$, and Fas at TNF- $\alpha$ and the Fas receptor and activates caspase enzymes responsible for apoptosis.

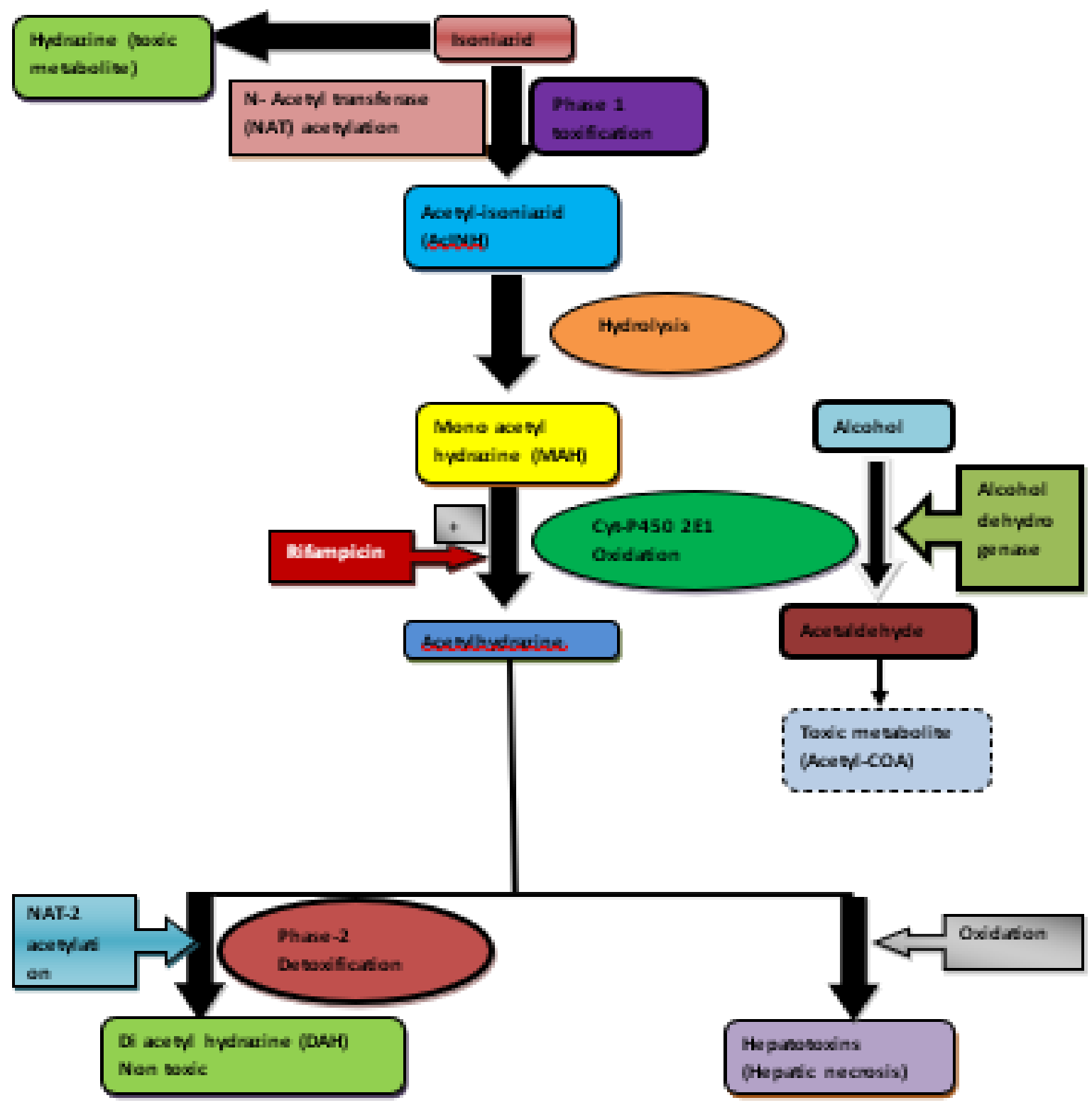

Figure 2: Mechanism of ATT-induced hepatotoxicity $31,32,33,34,35,38,39,62$

\section{Figure 2}

Isoniazid is metabolized to acetyl isoniazid in the presence of $\mathrm{N}$-acetyltransferase (NAT) when subjected to Phase 1 toxification. This step is followed by hydrolysis to mono acetyl hydrazine (MAH). Monoacetylhydrazine is oxidized in the presence of the microsomal enzyme cytochrome P4502E1 to acetyl hydrazine, which is ultimately oxidized to hepatotoxins, which leads to cell necrosis or apoptosis
In the presence of $\mathrm{N}$-acetyltransferase-2 (NAT-2), acetyl hydrazine is acetylated to diacetyl hydrazine, which is nontoxic, and this is phase 2 of liver poisoning. Rifampicin accelerates the formation of toxic metabolites by activating the production of cytochrome $\mathrm{P}-450$, which leads to cell damage. Alcohol is metabolized to acetaldehyde in the presence of CYP450 and Alcohol dehydrogenase enzyme leading to the formation of toxic metabolite in the liver. 


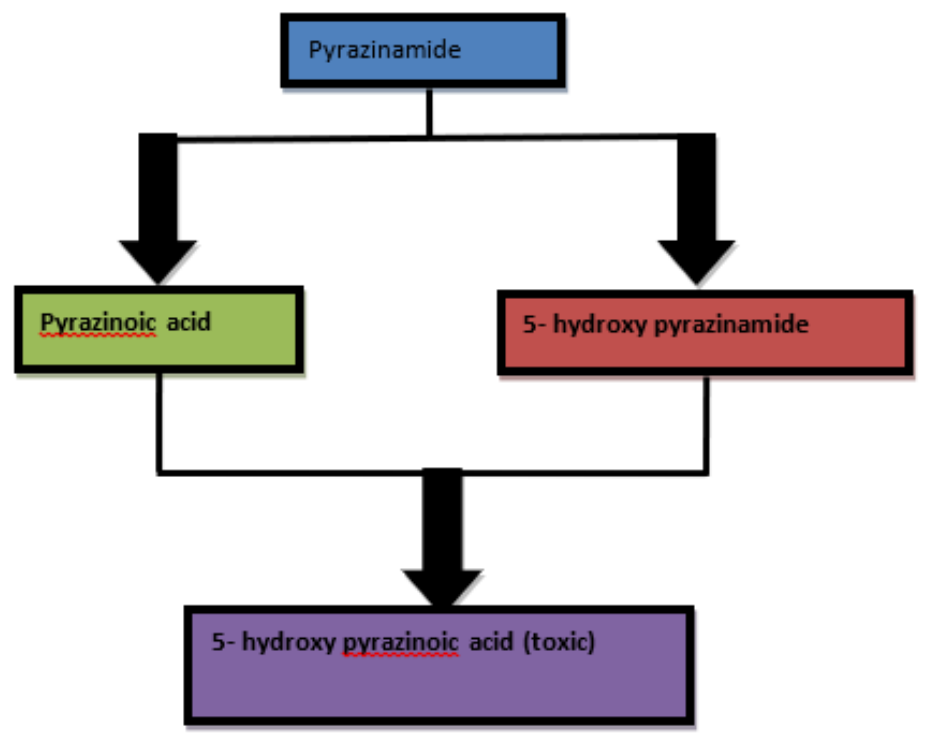

Figure 3: Metabolism of pyrazinamide 40,41

\section{Figure 3}

Pyrazinamide is metabolized either to pyrazinoic acid or 5hydroxypyrazinamide, both of these metabolites
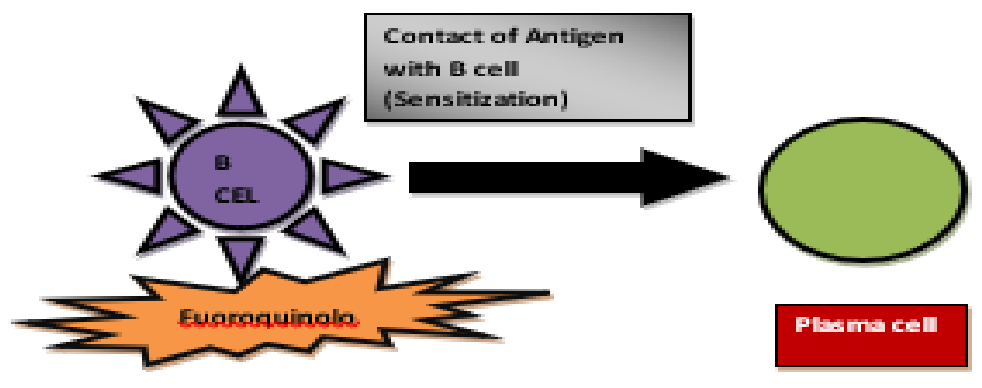

Plasma cell

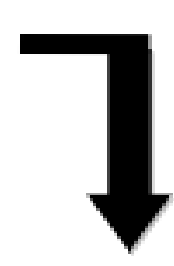

Secretes lef Antibodies ultimately metabolize to a toxic metabolite called 5hydroxy pyrazinoic acid.

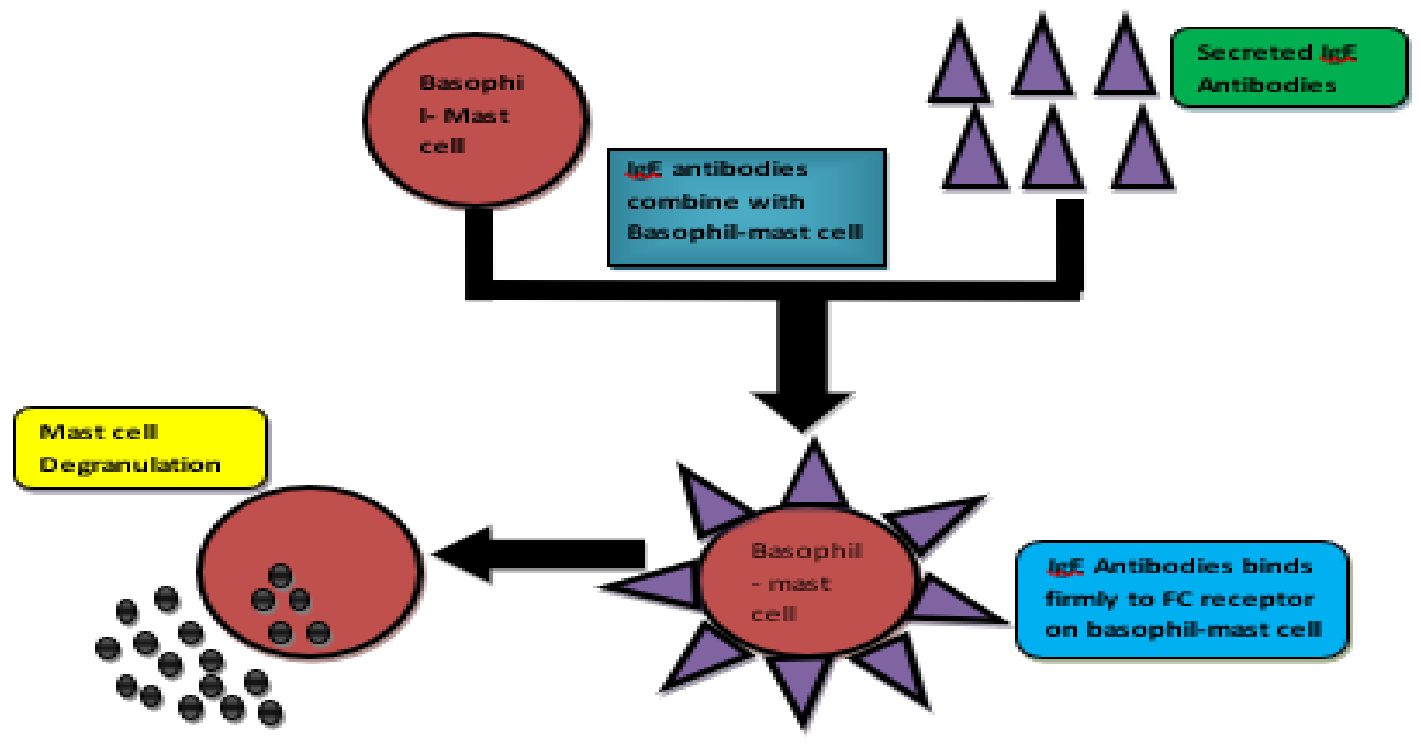

Figure 4: Type-1 anaphylactic hypersensitivity reaction to fluoroquinolones ${ }^{42}$

\section{Figure 4}

Fluoroquinolones bind to $B$ cells after administration in the body and secrete plasma cells by releasing IgE antibodies.
These antibodies bind to Basophil- mast cell via FC receptors. Due to this binding sodium and water enters the cell causing mast cell degranulation. 

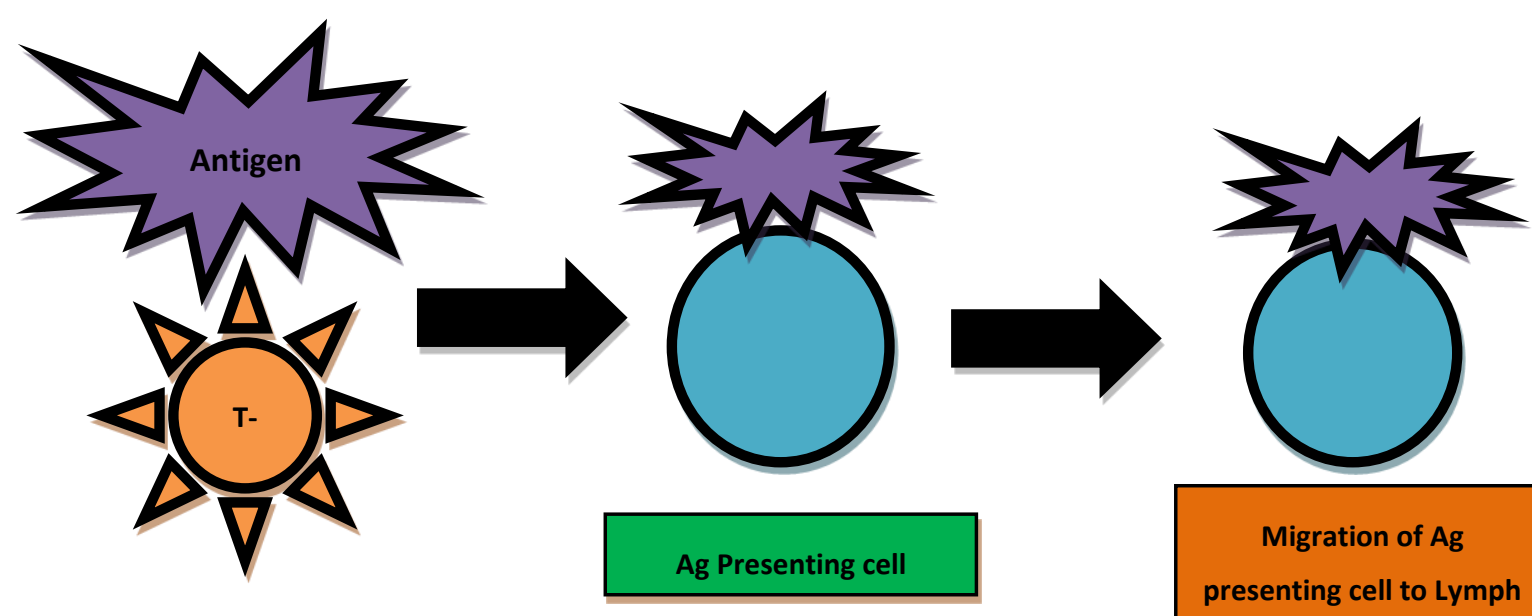

Migration of $\mathrm{Ag}$ presenting cell to Lymph node
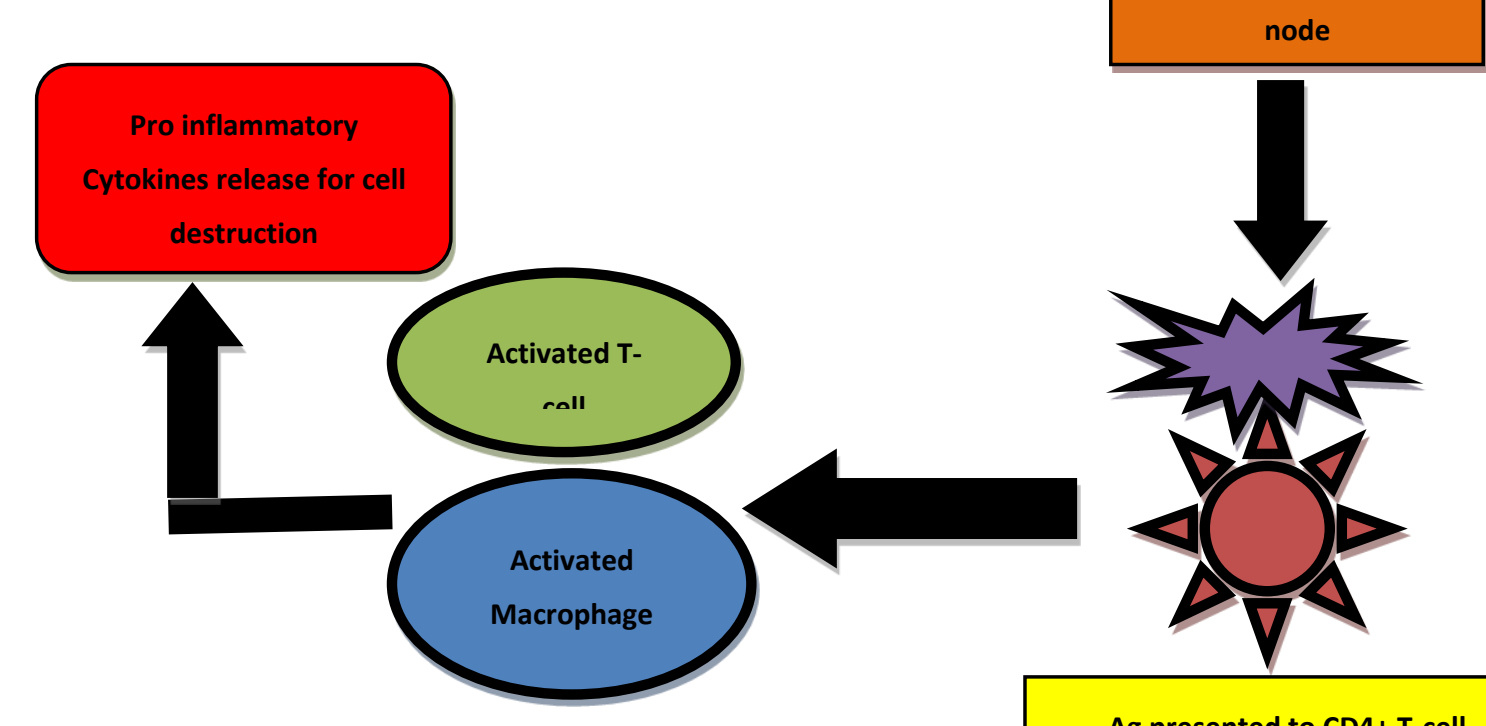

Ag presented to CD4+ T-cell

Figure: 5: Type-D delayed hypersensitivity reaction ${ }^{42}$

\section{Figure 5}

Fluoroquinolone (antigen) binds to T-cell after administration. T-cell presents antigen to an antigenpresenting cell which migrated to lymph node and further presents antigen to CD4-+ T-cell. CD4+ T cell activates macrophages and T-cells proliferation leading to cell rupture due to the release of cytokines and inflammatory mediators.

\section{Alcohol}

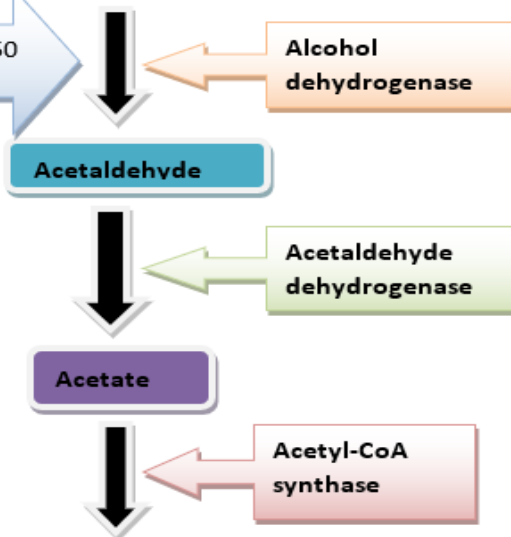

Acetyl-CoA

Figure 6: Alcohol metabolism ${ }^{61,62}$ 


\section{Figure 6}

Alcohol in the presence of CYP-450 and Alcohol dehydrogenase metabolizes to Acetaldehyde. Acetaldehyde is converted to Acetate in the presence of Acetaldehyde dehydrogenase. Toxic metabolite Acetyl CoA is synthesized from Acetate in the presence of Acetyl CoA.

\section{CONCLUSION}

It is the duty of the he pharmacist / medical staff has to provide the patient with adequate education about diseases and to inform them about their therapy regarding possible side effects and side effects. Pharmacists / medical staff must also train patients to comply with medication. All patient education takes place in the language preferred by the patient. Patients should be categorically instructed to report side effects or side effects such as nausea, vomiting, abdominal discomfort, or unexplained fatigue to the medical team immediately. Patients should visit the OPD at each follow-up visit to monitor LFT and reinforcement of education. Educate patients about alcohol consumption during therapy and how beneficial these hepatoprotective agents are to them.

Acknowledgements: The authors express regard and gratitude to his holiness Shri Mahant Devendra Das Ji Maharaj, Chairman, Shri Guru Ram Rai Education Mission, Dehradun, Uttarakhand, for providing the facilities required for our project work.

The authors acknowledge the support received from Shri Guru Ram Rai Institute of Technology and Science (SGRRITS), for their support and encouragement in carrying out his college work.

\section{REFERENCES}

1. World Health Organization. (2015) Global Tuberculosis Report 2015. 20 $0^{\text {th }}$ edition World Health Organization. Available from: https://www.gastrojournal.org/action/showPdf?pii=S001 6-5085\%2802\%2900241-X.

2. Treatment of Tuberculosis guidelines: 4th edition, World Health Organization; 2010. Available from: https://apps.who.int/iris/bitstream/handle/10665/44165/ 9789241547833 eng.pdf.

3. Khalil H, Dashti-Khavidaki S, Rasoolinejad M, Rezaie L, Etminani M. Anti-tuberculosis drugs related hepatotoxicity: incidence, risk factors, pattern of changes in liver enzymes and outcome. Daru J Pharm Sci. 2009; 17(3):163-67.

4. Brummer DL. Isoniazid and liver disease. Ann Intern Med. 1971; 75(4): 643-644. doi:10.7326/0003-4819-75-4-643.

5. Kopanoff DE, Snider DE Jr, Caras GJ. Isoniazid-related hepatitis: a U.S. Public Health Service cooperative surveillance study. Am Rev Respir Dis. 1978; 117(6) :9911001. doi:10.1164/arrd.1978.117.6.991.

6. Garibaldi RA, Drusin RE, Ferebee SH, Gregg MB. Isoniazidassociated hepatitis. Report of an outbreak. Am Rev Respir Dis. 1972; 106(3): 357-365. doi:10.1164/arrd.1972.106.3.357.

7. Black M, Mitchell JR, Zimmerman HJ, Ishak KG, Epler GR. Isoniazid-associated hepatitis in 114 patients. Gastroenterology. 1975; 69(2): 289-302.

8. Chitturi S, Farrell G. Drug-induced liver disease. In: Schiff ER, Sorrell MF, Maddrey WC, editors. Schiff's diseases of the liver, 9th ed. Philadelphia: Lippincott, Williams \& Wilkins, 2002; 1059-1128.

9. Larrey D. Epidemiology and individual susceptibility to adverse drug reactions affecting the liver. Semin Liver Dis. 2002; 22(2): 145-155. doi:10.1055/s-2002-30105.

10. Lee WM. Drug-induced hepatotoxicity. N Eng/ J Med. 1995; 333(17): 1118-1127. doi:10.1056/NEJM199510263331706.

11. Hwang $\mathrm{SJ}, \mathrm{Wu} \mathrm{JC}$, Lee $\mathrm{CN}$, et al. A prospective clinical study of isoniazid-rifampicin-pyrazinamide-induced liver injury in an area endemic for hepatitis B. J Gastroenterol Hepatol. 1997; 12(1): 87-91. doi:10.1111/j.1440-1746. 1997.tb00353. x.

12. Bénichou C. Criteria of drug-induced liver disorders. Report of an international consensus meeting. J Hepatol. 1990; 11(2): 272-276. doi:10.1016/0168-8278(90)90124-a

13. Yu YC, Mao YM, Chen CW, et al. CSH guidelines for the diagnosis and treatment of drug-induced liver injury. Hepatol Int. 2017; 11(3): 221-241. doi:10.1007/s12072-017-9793-2

14. Sharma SK, Ryan H, Khaparde S, et al. Index-TB guidelines: Guidelines on extrapulmonary tuberculosis for India. Indian J Med Res. 2017; 145(4): 448-463. doi: 10.4103/ijmr.IJMR_1950_16.

15. Moore EE, Cogbill TH, Jurkovich GJ, Shackford SR, Malangoni MA, Champion HR. Organ injury scaling: spleen and liver (1994 revision). J Trauma. 1995; 38(3): 323-324. doi:10.1097/00005373-199503000-00001.

16. Piper GL, Peitzman AB. Current management of hepatic trauma. Surg Clin North Am. 2010; 90(4): 775-785. doi: 10.1016/j.suc.2010.04.009.

17. Table 8 Liver Injury Scale American Association for the Surgery of Trauma (AAST) (2018) revision. Available from: https://www.aast.org/resources-detail/injury-scoringscale\#liver

18. Tostmann A, Boeree MJ, Aarnoutse RE, de Lange WC, van der Ven AJ, Dekhuijzen R. Antituberculosis drug-induced hepatotoxicity: concise up-to-date review. J Gastroenterol Hepatol. 2008; 23(2): 192-202. doi:10.1111/j.14401746.2007. 05207.x

19. Saukkonen JJ, Cohn DL, Jasmer RM, Schenker S, Jereb JA, Nolan CM, Peloquin CA, Gordin FM, Nunes D, Strader DB, et al. An official ATS statement: hepatotoxicity of antituberculosis therapy. Am J Respir Crit Care Med 2006; 174(8): 935-52. DOI: 10.1164/rccm.200510-1666ST.

20. Parthasarathy R, Sarma GR, Janardhanam B, et al. Hepatic toxicity in South Indian patients during treatment of tuberculosis with short-course regimens containing isoniazid, rifampicin and pyrazinamide. Tubercle. 1986; 67(2): 99-108. doi:10.1016/0041-3879(86)90003-6.

21. Purohit SD, Gupta PR, Sharma TN, Gupta DN, Chawla MR. Rifampicin and hepatic toxicity. Indian J Tuberc 1983; 30: 107-9.

22. Taneja DP, Kaur D. Study on hepatotoxicity and other sideeffects of antituberculosis drugs. J Indian Med Assoc. 1990; 88(10): 278-280. 
23. Mehta S. Malnutrition and drugs: clinical implications. Dev Pharmacol Ther. 1990; 15(3-4): 159-165. doi:10.1159/000457640.

24. Yun $\mathrm{CH}$, Okerholm RA, Guengerich FP. Oxidation of the antihistaminic drug terfenadine in human liver microsomes. Role of cytochrome P-450 3A (4) in Ndealkylation and C-hydroxylation. Drug Metab Dispos. 1993; 21(3): 403-409.

25. Beaune $P$, Dansette PM, Mansuy D, et al. Human antiendoplasmic reticulum autoantibodies appearing in a druginduced hepatitis are directed against a human liver cytochrome P-450 that hydroxylates the drug. Proc Nat/ Acad Sci U S A. 1987; 84(2): 551-555. doi:10.1073/pnas.84.2.551.

26. Trauner M, Meier PJ, Boyer JL. Molecular pathogenesis of cholestasis. N Engl J Med. 1998; 339(17): 1217-1227. doi:10.1056/NEJM199810223391707.

27. Robin MA, Le Roy M, Descatoire V, Pessayre D. Plasma membrane cytochromes P450 as neoantigens and autoimmune targets in drug-induced hepatitis. $J$ Hepatol. 1997;26 Suppl 1: 23-30. doi:10.1016/s01688278(97)82329-x.

28. Reed JC. Apoptosis-regulating proteins as targets for drug discovery. Trends Mol Med. 2001; 7(7): 314-319. doi:10.1016/s1471-4914(01)02026-3.

29. Pessayre D, Berson A, Fromenty B, Mansouri A. Mitochondria in steatohepatitis. Semin Liver Dis. 2001; 21(1): 57-69. doi:10.1055/s-2001-12929.

30. Kishore PV, Palaian S, Paudel R, Mishra P, Prabhu M, Shankar PR. Drug induced hepatitis with anti-tubercular chemotherapy: challenges and difficulties in treatment. Kathmandu Univ Med J (KUMJ). 2007; 5(2): 256260.

31. Mitchell JR, Zimmerman HJ, Ishak KG, Thorgeirsson UP, Timbrell JA, Snodgrass WR, Nelson SD. Isoniazid liver injury: clinical spectrum, pathology and probable pathogenesis. Ann Intern Med 1976; 84(2): 181-192. DOI: 10.7326/00034819-84-2-181.

32. Farrell GC. Drug-induced acute hepatitis. In: Farrell GC, ed. Drug-induced liver disease. Edinburgh: Churchill Livingstone, 1994: 247-299.

33. Ryan $D E$, Ramanathan $L$, lida $S$, Thomas $P E$, Haniu $M$, Shively JE, Lieber CS, et al. Characterization of a major form of rat hepatic microsomal cytochrome P-450 induced by isoniazid. J Biol Chem 1985; 260(10): 6385-6393. doi.org/10.1016/S0021-9258 (18)88984-0.

34. Huang YS, Chern HD, Su WJ, et al. Polymorphism of the Nacetyltransferase 2 gene as a susceptibility risk factor for antituberculosis drug-induced hepatitis. Hepatology. 2002; 35(4): 883-889. doi:10.1053/jhep.2002.32102

35. Grönhagen-Riska C, Hellstrom PE, Fröseth B. Predisposing factors in hepatitis induced by isoniazid-rifampin treatment of tuberculosis. Am Rev Respir Dis. 1978; 118(3): 461-466. doi:10.1164/arrd.1978.118.3.461.

36. Girling DJ. The hepatic toxicity of antituberculosis regimens containing isoniazid, rifampicin and pyrazinamide. Tubercle. 1978; 59(1): 13-32. doi:10.1016/0041-3879(77)90022-8.
37. Pande JN, Singh SP, Khilnani GC, Khilnani S, Tandon RK. Risk factors for hepatotoxicity from antituberculosis drugs: a case-control study. Thorax. 1996; 51(2): 132-136. doi:10.1136/thx.51.2.132

38. Watkins PB. The role of cytochrome P450s in drug-induced liver disease. In: Kaplowitz N, Deleve LD, eds. Drug-Induced Liver Disease. New York: Marcel Dekker, 2003: 1533.

39. Hussain Z, Kar P, Husain SA. Antituberculosis drug-induced hepatitis: risk factors, prevention and management. Indian J Exp Biol. 2003; 41(11): 1226-1232.

40. Whitehouse LW, Lodge BA, By AW, Thomas BH. Metabolic disposition of pyrazinamide in the rat: identification of a novel in vivo metabolite common to both rat and human. Biopharm Drug Dispos. 1987; 8(4): 307-318. doi:10.1002/bdd.2510080402

41. Lacroix C, Hoang TP, Nouveau J, et al. Pharmacokinetics of pyrazinamide and its metabolites in healthy subjects. Eur $J$ Clin Pharmacol. 1989; 36(4): 395-400. doi:10.1007/BF00558302.

42. Mohan Harsh, Textbook of Pathology, $7^{\text {th }}$ Edition New Delhi, London, Philadelphia, Panama, 2015: Page: 58-61.

43. Gangadharam PR. Isoniazid, rifampin, and hepatotoxicity. Am Rev Respir Dis. 1986; 133(6): 963-965. doi:10.1164/arrd.1986.133.6.963

44. Snider DE Jr, Roper WL. The new tuberculosis. $N$ Engl J Med. 1992; 326(10): 703-705. doi:10.1056/NEJM199203053261011

45. Singla R, Sharma SK, Mohan A, et al. Evaluation of risk factors for antituberculosis treatment induced hepatotoxicity. Indian J Med Res. 2010; 132: 81-86.

46. Ben Mahmoud L, Ghozzi H, Kamoun A, et al. Polymorphism of the $\mathrm{N}$-acetyltransferase 2 gene as a susceptibility risk factor for antituberculosis drug-induced hepatotoxicity in Tunisian patients with tuberculosis. Pathol Biol (Paris). 2012; 60(5): 324-330. doi: 10.1016/j.patbio.2011.07.001

47. Mahmood K, Hussain A, Jairamani KL, Talib A, Abbasi B, Salkeen $\mathrm{S}$. Hepatotoxicity with antituberculosis drugs: the risk factors. Pak J Med Sci., 2007; 23: 33-38.

48. Ohno M, Yamaguchi I, Yamamoto I, et al. Slow Nacetyltransferase 2 genotype affects the incidence of isoniazid and rifampicin-induced hepatotoxicity. Int $J$ Tuberc Lung Dis. 2000; 4(3): 256-261.

49. Steele MA, Burk RF, DesPrez RM. Toxic hepatitis with isoniazid and rifampin. A meta-analysis. Chest. 1991; 99(2): 465-471. doi:10.1378/chest.99.2.465.

50. Timbrell JA, Park BK, Harland SJ. A study of the effects of rifampicin on isoniazid metabolism in human volunteer subjects. Hum Toxicol. 1985; 4(3): 279-285. doi:10.1177/096032718500400308

51. Fernández-Villar A, Sopeña B, Fernández-Villar J, et al. The influence of risk factors on the severity of anti-tuberculosis drug-induced hepatotoxicity. Int J Tuberc Lung Dis. 2004; 8(12): 1499-1505.

52. Papastavros T, Dolovich LR, Holbrook A, Whitehead L, Loeb $M$. Adverse events associated with pyrazinamide and levofloxacin in the treatment of latent multidrug-resistant tuberculosis. CMAJ. 2002; 167(2): 131-136. 
53. Younossian AB, Rochat T, Ketterer JP, Wacker J, Janssens JP. High hepatotoxicity of pyrazinamide and ethambutol for treatment of latent tuberculosis. Eur Respir J. 2005; 26(3): 462-464. doi:10.1183/09031936.05.00006205.

54. Ridzon R, Meador J, Maxwell R, Higgins K, Weismuller P, Onorato IM. Asymptomatic hepatitis in persons who received alternative preventive therapy with pyrazinamide and ofloxacin. Clin Infect Dis., 1997; 24(6): 1264-1265. doi.org/10.1093/clinids/24.6.1264.

55. Huang YS, Chern HD, Su WJ, et al. Cytochrome P450 2E1 genotype and the susceptibility to antituberculosis druginduced hepatitis. Hepatology. 2003; 37(4): 924-930. doi:10.1053/jhep.2003.50144.

56. Smith CA, Wadelius M, Gough AC, Harrison DJ, Wolf CR, Rane A. A simplified assay for the arylamine $\mathrm{N}$ acetyltransferase 2 polymorphism validated by phenotyping with isoniazid. J Med Genet. 1997; 34(9): 758760. doi:10.1136/jmg.34.9.758

57. Björnsson E. Review article: drug-induced liver injury in clinical practice. Aliment Pharmacol Ther. 2010; 32(1): 313. doi:10.1111/j.1365-2036.2010.04320.x

58. Marvin W. Impacts of gender on drug responses. Drug Top, 1998; 591-600.

59. Attri S, Rana SV, Vaiphie K, et al. Protective effect of Nacetylcysteine in isoniazid induced hepatic injury in growing rats. Indian J Exp Biol. 2001; 39(5): 436-440.

60. Sodhi CP, Rana SV, Mehta SK, et al. Study of oxidative stress in isoniazid-induced hepatic injury in young rats with and without protein-energy malnutrition. J Biochem Toxicol. 1996; 11(3): 139-146. doi:10.1002/(SICI)15227146(1996)11: 3<139:AID-JBT6>3.0.CO;2-L.

61. Makhlouf HA, Helmy A, Fawzy E, El-Attar M, Rashed HA. A prospective study of antituberculous drug-induced hepatotoxicity in an area endemic for liver diseases. Hepatol Int. 2008; 2(3): 353-360. doi:10.1007/s12072-008-9085-y.

62. Hunt CM, Westerkam WR, Stave GM. Effect of age and gender on the activity of human hepatic CYP3A. Biochem Pharmacol. 1992; 44(2): 275-283. doi:10.1016/00062952(92)90010-g.

63. Holdiness MR. Clinical pharmacokinetics of the antituberculosis drugs. Clin Pharmacokinet. 1984; 9(6): 511-544. doi:10.2165/00003088-198409060-00003.

64. Sarma GR, Immanuel C, Kailasam S, Narayana AS, Venkatesan P. Rifampin-induced release of hydrazine from isoniazid. A possible cause of hepatitis during treatment of tuberculosis with regimens containing isoniazid and rifampin. Am Rev Respir Dis. 1986; 133(6): 1072-1075. doi:10.1164/arrd.1986.133.6.1072.

65. Buchanan N, Eyberg C, Davis MD. Isoniazid pharmacokinetics in kwashiorkor. S Afr Med J. 1979; 56(8): 299-300.

66. Walter-Sack I, Klotz U. Influence of diet and nutritional status on drug metabolism. Clin Pharmacokinet. 1996; 31(1): 47-64. doi:10.2165/00003088-199631010-00004.

67. Anand AC, Seth $A K$, Paul M, Puri P. Risk Factors of Hepatotoxicity During Anti-tuberculosis Treatment. Med J
Armed Forces India. 2006; 62(1): 45-49. doi:10.1016/S0377-1237(06)80155-3.

68. Dworkin MS, Adams MR, Cohn DL, et al. Factors that complicate the treatment of tuberculosis in HIV-infected patients. J Acquir Immune Defic Syndr. 2005; 39(4): 464470. doi: 10.1097/01.qai.0000152400.36723.85.

69. Ungo JR, Jones D, Ashkin D, et al. Antituberculosis drug induced hepatotoxicity. The role of hepatitis $\mathrm{C}$ virus and the human immunodeficiency virus. Am J Respir Crit Care Med. 1998; 157(6Pt1): 1871-1876 doi:10.1164/ajrccm.157.6.9711039.

70. Green RM, Flamm Steven, AGA technical review on the evaluation of liver chemistry tests. Am Gastroenterological Association, 2002; 123(4): 1367-1384. Doi: https://doi.org/10.1053/gast.2002.36061.

71. Wang JY, Liu CH, Hu FC, et al. Risk factors of hepatitis during anti-tuberculous treatment and implications of hepatitis virus load.J Infect. 2011; 62(6): 448-455. doi: 10.1016/j.jinf.2011.04.005.

72. Mehta PJ, Joshi SR, Mehta Nihar Practical Medicine, $20^{\text {th }}$ Edition, 2017, page: 166-167.

73. Implementing the WHO Stop TB Strategy: A Handbook for National Tuberculosis Control Programmes. Geneva: World Health Organization; 2008. 2, Treatment of tuberculosis patients. Available from: https://www.ncbi.nlm.nih.gov/books/NBK310759/

74. Leuschner U, Leuschner M, Sieratzki J, Kurtz W, Hübner K. Gallstone dissolution with ursodeoxycholic acid in patients with chronic active hepatitis and two years follow-up. A pilot study. Dig Dis Sci. 1985; 30(7): 642-649. doi:10.1007/BF01308413.

75. Leuschner $\mathrm{U}$, Fischer $\mathrm{H}$, Kurtz W, et al. Ursodeoxycholic acid in primary biliary cirrhosis: results of a controlled doubleblind trial. Gastroenterology. 1989; 97(5): 1268-1274. doi:10.1016/0016-5085(89)91698-3.

76. Cirillo NW, Zwas FR. Ursodeoxycholic acid in the treatment of chronic liver disease. Am J Gastroenterol. 1994; 89(9):1447-1452.

77. Leuschner U. Ursodeoxycholic acid therapy in primary biliary cirrhosis. Scand J Gastroenterol Suppl. 1994; 204: 40-46. doi:10.3109/00365529409103624

78. lino $\mathrm{S}$, Tango $\mathrm{T}$, Matsushima $\mathrm{T}$, et al. Therapeutic effects of stronger neo-minophagen $\mathrm{C}$ at different doses on chronic hepatitis and liver cirrhosis. Hepatol Res. 2001; 19(1): 3140. doi:10.1016/s1386-6346(00)00079-6.

79. Sehar Sana, Munir Afia, Chandni Tooba and Ahmad Muhammad, Frequency of First Line Antituberculosis Drug Induced Hepatitis, Proceeding S.Z.P.G.M.I. 2017; 31(2): 5661.

80. Singh J, Garg PK, Thakur VS, Tandon RK. Anti-tubercular treatment induced hepatotoxicity: does acetylator status matter? Indian J Physiol Pharmacol. 1995; 39(1): 43-46.

81. Rahman N, Ali S, Khan MY, Umar M, Iqbal Z, Basit A, Ullah Z, Javaid A, Frequency of Risk Factors for Hepatotoxicity in patients with Antituberculosis Drug Induced Hepatitis, PJCM 2015; 21(1): 4-9. 
82. Chang KC, Leung CC, Yew WW, Tam CM. Standard antituberculosis treatment and hepatotoxicity: do dosing schedules matter? Eur Respir J. 2007; 29(2): 347-351. doi:10.1183/09031936.00090306.

83. J Singh, A Arora, PK Garg, VS Thakur, JN Pande, RK Tandon, Antituberculosis treatment-induced hepatotoxicity: role of predictive factors, Postgrad MedJ 1995; 71: 359-362.

84. Malik IM, Naz HS, Hassan GU, Frequency of ATT Induced Hepatitis in Newly Diagnosed Pulmonary TB Patients, P J M H S 2014; 8(3): 533-535.

85. Abbasi MA, Ahmed N, Suleman A, et al. Common risk factors for the development of anti- tuberculosis treatment induced hepatotoxicity. J Ayub Med Coll Abbottabad. 2014; 26(3): 384-388.

86. Tariq S, Khan TS, Malik S, Anwar MS, Rashid A. Frequency of anti-tuberculous therapy-induced hepatotoxicity in patients and their outcome. J Ayub Med Coll Abbottabad. 2009; 21(4): 50-52.
87. Bartaula, B., Pradhan, B., Bhatta, N., Pandey, N.K., Baral, D.D., Mudbhari, B., 2017. Study of Predictive Factors of Anti Tuberculosis Treatment Induced Hepatotoxicity. Eur. J. Biomed. Pharm. Sci. 2017; 4: 210-15.

88. Gaude GS, Chaudhury A, Hattiholi J. Drug-induced hepatitis and the risk factors for liver injury in pulmonary tuberculosis patients. J Family Med Prim Care. 2015; 4(2): 238-243. doi:10.4103/2249-4863.154661.

89. Mahmood K, Hussain A, Jairamani KL, Talib A, Abbasi BU. Salkeen S, Hepatotoxicity with Antituberculosis Drugs: The Risk Factors, Pak J Med Sci 2007 23(1): 33-38.

90. Khoharo HK, Ansari S, Siddiqui AA, Qureshi F, Standard Antituberculosis Drug Induced Hepatotoxicity: Do the Risk Factors Matter, J. Liaquat Univ. Med. Health Sci.2010; 9(2): 84-87.

Source of Support: The author(s) received no financial support for the research, authorship, and/or publication of this article.

Conflict of Interest: The author(s) declared no potential conflicts of interest with respect to the research, authorship, and/or publication of this article.

For any question relates to this article, please reach us at: editor@globalresearchonline.net New manuscripts for publication can be submitted at: submit@globalresearchonline.net and submit_ijpsrr@rediffmail.com 